\title{
IS AN INTEGRATED REGIONAL \\ LABOR MARKET EMERGING IN \\ EAST AND SOUTHEAST ASIA?
}

David E. Bloom

Waseem Noor

Working Paper No. 5174

\section{NATIONAL BUREAU OF ECONOMIC RESEARCH 1050 Massachusetts Avenue \\ Cambridge, MA 02138 \\ July 1995}

The authors would like to thank Min Tang, Pasuk Phongpaichit, Duncan Campbell, Aurelio Parisotto, and other participants at an International Labour Organisation conference in Bangkok for helpful discussions and comments. The authors would also like to thank Pracha Vasuprasat and Manola Abella for help in accessing labor migration data, and the ILO's International Institute for Labor Studies for financial support. This paper is part of NBER's research programs in International Trade and Investment, and Labor Studies. Any opinions expressed are those of the authors and not those of the National Bureau of Economic Research.

(C) 1995 by David E. Bloom and Waseem Noor. All rights reserved. Short sections of text, not to exceed two paragraphs, may be quoted without explicit permission provided that full credit, including (C) notice, is given to the source. 
IS AN INTEGRATED REGIONAL

LABOR MARKET EMERGING IN

EAST AND SOUTHEAST ASIA?

\begin{abstract}
We examine labor market integration in east and southeast Asia (ESEA) during the 1980s, focusing on intraregional labor mobility and on the two other main channels of integration: capital mobility and trade. We find evidence that labor market integration increased sharply among ESEA countries in the 1980s, with 9 percent of ESEA's labor force participating either directly via labor mobility or indirectly via capital mobility or trade in cross-national labor market transactions in 1991, up from just 5.2 percent in 1980. We also find that trade is the dominant mechanism through which regional labor market integration occurred in the 1980 s, with labor migration contributing only modestly to the process.
\end{abstract}

David E. Bloom

Department of Economics

Columbia University

New York, NY 10027

and NBER
Waseem Noor

Department of Economics

Columbia University

New York, NY 10027 


\section{Is an Integrated Regional Labor Market Emerging in East and Southeast Asia?*}

Economic growth is the leading concern of macroeconomic policymakers. In traditional macroeconomic models, the main factors that promote economic growth are labor force growth, physical and human capital accumulation, changes in the allocation of resources across economic sectors, and technological advancement. All these factors are influenced by the integration of national economies, a process that has gained considerable momentum in recent years because of the erosion of economic and institutional barriers to an integrated world economy (see Bloom and Brender 1993; Ehrenberg 1994; World Bank 1995).

Discussing the integration of particular factor and product markets is commonplace. The movement of labor between countries is the standard indicator of international labor market integration. Similarly, cross-national mobility of physical or financial capital is the standard indicator of international capital market integration, while trade is the standard indicator of international product market integration. However, integration of particular markets occurs not only through international transactions involving corresponding factors or products, but also through transactions involving other factors or products. Indeed, a fundamental premise of economic theory holds that the labor markets in two countries effectively become integrated when there is either trade, capital mobility, or labor mobility between them.

Capital mobility typically represents jobs searching for workers, which is closely related to labor mobility, which represents workers searching for jobs. For example, when a Japanese company establishes an automobile assembly plant in Indonesia, it expresses a demand for Indonesian labor in Indonesia. Labor market integration between the two countries takes place

\footnotetext{
* The authors would like to thank Dr. Min Tang, Dr. Pasuk Phongpaichit, Dr. Duncan Campbell, Mr. Aurelio Parisotto, and other participants at an International Labour Organisation conference in Bangkok for helpful discussions and comments. The authors would also like to thank Mr. Pracha Vasuprasat and Mr. Manola Abella for help in accessing labor migration data, and the ILO's International Institute for Labor Studies for financial support.
} 
when the Japanese set up factories in Indonesia just as when Indonesian workers migrate to Japan to work in Japanese factories. Both cases involve international labor market transactions, with Indonesian workers selling labor services to Japanese firms.

National labor markets may also become integrated though trade. When a country exports a good it implicitly also exports the labor services embodied in producing that good. For example, the export of domestically produced electronic goods from Singapore to Malaysia is roughly equivalent, from the standpoint of labor utilization, to the export of Singaporean capital and labor to Malaysia where they are used to produce the same goods for local sale. Transportation and other costs of labor, capital, and product mobility are key determinants of which option Singaporean firms choose for supplying electronic goods to Malaysian consumers.

The purpose of this paper is to examine labor market integration as it has been achieved through labor mobility, capital mobility, and trade in east and southeast Asia (ESEA). We do this by examining aggregate data on each of these three related channels of integration during the 1980 s, leaving to this volume's other contributors the task of exploring the microeconomic aspects of labor market integration, such as vertical integration of private industries between countries (Gereffi 1995) and the emergence of "growth triangles" (Teal 1995; Thant and Tang 1995; Thant, Tang, and Kakazu 1994). We compare integration within ESEA with integration involving ESEA and other regions. We also assess the relative contributions of labor mobility, capital mobility, and trade to labor market integration within the region. In addition, we discuss the pattern of regional labor market integration during the $1980 \mathrm{~s}$ in light of changes that occurred in incentives for integration and in various institutional and economic barriers to integration. We conclude by speculating on the prospects for, and implications of, further integration.

\section{Conceptual Framework}

We begin by distinguishing between the concepts of labor market interdependence and labor market integration. Labor market interdependence refers to the extent to which 
perturbations in one country's economy are felt in other countries' labor markets. Interdependence is thus promoted by the absence of barriers to factor mobility and trade. These barriers may be purely economic, for example, transportation costs, or they may be institutional, as in the case of legal restrictions on labor mobility and technology transfer or tariffs and quotas.

By contrast, labor market integration refers to the extent of factor mobility and trade between two or more economies. Thus, even if two economies are not integrated, perhaps because the structure of their economies is so similar that it eliminates the possibility of gains to factor mobility and trade, they may still be interdependent in the sense that a shock experienced in one economy creates incentives for integrated economic activity.

Much has been written about the causes and consequences of international labor mobility (see ILO 1992; Macmillen 1982; UN 1992c), with most researchers viewing migration as a response to spatial differences in labor market conditions (see Abella and Mori 1994; Borjas 1990; Stark 1991). Similarly, spatial arbitrage is the core idea in most studies of capital market integration, with these studies focusing primarily on four areas: (a) the magnitude of total capital flows (see Chen 1992; Chen 1993; Ruffin 1993; Yue 1993); (b) the resulting parity of interest rates across integrated areas (see Haque and Montiel 1991; Mishkin 1984); (c) the correlation between investment rates and domestic savings rates (Feldstein and Horioka 1980; Frankel 1985) and (d) the intertemporal behavior of individuals in different countries through tests of Euler equations for consumption (Obstfeld 1986). Montiel (1994) presents a detailed comparison of these different indicators of capital market integration.

International trade is driven by comparative advantage, which in turn, according to the standard Heckscher-Ohlin trade model, is determined by the relative stocks of production factors across countries. Countries export goods in which they have a comparative advantage, resulting in the equalization of product and factor prices between trading partners. Assuming that production technologies are identical for all trading partners, a powerful implication of the Heckscher-Ohlin model is that trade can lead to full integration of product, capital, and labor markets even in the absence of international factor movements. Razin and Sadka (1992) point out 
that international factor mobility reinforces the integrating effects of trade on factor and product markets.

In addition to the integration of markets, free international trade also results in increased income for all trading partners as well as improvements in their welfare. Recently some industrial countries have argued that many domestic, labor-intensive jobs have been "siphoned" away by newly industrializing countries in ESEA. Baldwin (1995) reviews studies of the impact of changing trade patterns on domestic labor markets. He concludes that changes in employment and relative wages are generally not attributable to evolving trade conditions. Despite employment declines in particular industries, the employment-creating effects of trade have outweighed the employment-displacing effects. ${ }^{1}$

Even though economic theory suggests that trade alone can potentially substitute for capital and labor mobility in integrating markets between trading partners, empirically this situation is rarely found. Rather, high levels of factor flows are typically associated with high levels of trade flows (Riedel 1992). Note also that labor mobility does not have the same social or political implications as capital mobility, especially when there are religious, ethnic, or racial differences between migrants and the host country population. Thus, while movements of labor and capital have similar effects in promoting factor market integration, they should not be viewed as perfectly interchangeable. Finally, it is worth noting that at a global level, integration appears thus far to be more an industrial country than a developing country phenomenon, contributing significantly to income growth in the industrial countries and reducing disparities in their per capita incomes (Bloom and Brender 1993).

\footnotetext{
${ }^{1}$ Along with the standard effects of trade and factor mobility, economic integration also spreads the cost of economic shocks across integrated markets. For example, the economic consequences of a fall in the demand for one country's timber because of growing environmental awareness can be diminished by the outmigration of forestry workers from that country.
} 


\section{Empirical Results}

Previous empirical work on the topic of economic integration in ESEA has looked mainly at the growth of capital movements and trade. Yue (1993) and Chen (1993) both document the increased scale of foreign direct investment in ESEA, although they do not distinguish between intra and interregional investment. Jha (1994) analyzes the growth of intraregional trade, but does not compare his findings with the amount of trade carried out with the rest of the world. Riedel (1992) investigates the link between trade and capital movements within ESEA and finds evidence of a strong positive association between trade and capital movements. The present analysis builds on these studies by examining intraregional labor mobility in addition to intraregional trade and capital mobility, and also by assessing the relative contributions of each mechanism to labor market integration in ESEA since the early 1980s. For empirical purposes, ESEA comprises ten economies: China, Hong Kong, Indonesia, Japan, the Republic of Korea, Malaysia, the Philippines, Singapore, Taiwan, and Thailand. Kampuchea, Laos, and Vietnam are excluded because of a lack of data.

\section{A. Movements of Labor}

The labor migration data analyzed in this section were obtained from various International Labour Organisation (ILO) publications and through personal correspondence with ILO staff in Bangkok. Unfortunately, the data only refer to the number of documented migrants from the major labor-sending countries of ESEA. The difficulty in assembling reliable data on total labor migration is widely recognized, and is due to both a lack of coordination between labor-sending and labor-receiving countries and to substantial flows of undocumented migrants (see Athukorala 1993; UNDP/ILO 1993).

Table 1 shows the distribution of labor migrants from Indonesia, Korea, the Philippines, and Thailand - ESEA's major labor-sending countries - among groups of destination countries. Also reported are average annual growth rates for total numbers of migrants from the four labor-sending countries to each destination. The growth rates are estimated by regressing the 
natural logarithm of annual migration outflows on a simple time trend. For the four countries as a whole they show a 4.2 percent rate of annual increase. However, the number of outmigrants destined for ESEA countries grew more than four times as fast (18 percent per year), outpacing the growth of migration to all other destination groups in the table. Thus, intercountry labor mobility within ESEA appears to have increased sharply during the 1980 s

By far, the dominant share of outmigrants from the four ESEA labor-sending countries moved to the Middle East throughout the 1980s, but this share fell precipitously from 88 to 62 percent between 1980-82 and 1989-91 as falling oil prices resulted in essentially zero growth in the number of Middle East migrants from ESEA. By contrast, the share of ESEA migrants destined for other Asian countries more than trebled, another indication of sharply increased intraregional labor mobility.

Table 2 reports the distribution of destinations for labor migrants from Indonesia, the Philippines, and Thailand. Examination of these distributions reveals that virtually all migrants from these three countries moved to countries with higher per capita income. This migration pattern is consistent with the most basic economic model of migration, in which labor mobility is driven by the search for higher wages. Unfortunately, the main implication of this model - the fall in wage differentials as labor markets become more integrated - is not testable here because of a lack of appropriate data. An analysis of cross-country differentials in income per capita reveals increased inequality from 1979 to 1987 and declining inequality through 1992, with a small net increase for the overall period. ${ }^{2}$ However, as per capita income reflects hourly wages, hours worked, and unearned income and is subject to many influences not controlled for, this finding does not necessarily contradict the hypothesis that integration promotes convergence in wages across countries.

Most labor experts believe that ESEA's reported labor migration omits a large flow of undocumented migration. Rough estimates place the level of undocumented migrants at 40 to 50

\footnotetext{
${ }^{2}$ We computed Gini coefficients using per capita income data for the ESEA countries. The estimates increased from 0.51 to 0.56 from 1979 to 1987 , but fell to 0.54 in 1992 .
} 
percent of total migration, suggesting that the true flow of intraregional migrants could be as much as double the figures reported in table 2. Available evidence indicates that most of ESEA's documented intraregional migrants are unskilled and low-skill workers, a pattern that would almost certainly be accentuated if data were available on the skill distribution of undocumented migrants.

Intraregional labor migration flows are quite small in relation to the overall size of the labor force in the major labor-receiving economies of ESEA (that is, Hong Kong, Japan, Malaysia, Singapore, and Taiwan). Even doubling the reported numbers as a crude adjustment for undocumented migration suggests there were only 470,000 intraregional migrants in 1991, about 0.6 percent of the total work force in these countries. Although the necessary data are not available, this percentage would be even smaller if one were able to measure net migration. Even if one assumes that migrants stay about five years, total labor migration would only account for about 2 percent of the total labor force in ESEA's labor-receiving countries.

Although foreign workers accounted for a relatively small share of work force size in the labor-receiving countries of ESEA, labor migration accounted for a relatively large share of labor force growth in those countries. Documented migrants alone constituted about one-third of labor force growth in 1991. To the extent that undocumented migrants are counted as part of the labor force (assuming a doubling of documented migrant numbers), total labor migrants, averaging roughly 200,000 workers per year in ESEA's labor-receiving countries during the 1980s, would account for the bulk of work force growth. Thus, intraregional labor mobility in ESEA, although it is not a large share of the total labor force, appears to contribute significantly to annual labor force growth in the labor-receiving countries of ESEA. ${ }^{3}$ Among the labor-sending countries, outmigration reduced labor force expansion by about 13 percent between 1990 and 1991, thus serving to even out, albeit slightly, the supply of labor across countries within ESEA.

\footnotetext{
${ }^{3}$ In terms of direct evidence, the foreign-born share of the Japanese population was a paltry 0.6 percent in 1980 and consisted mostly of Koreans. The foreign-born share increased only slightly during the $1980 \mathrm{~s}$, reaching 0.7 percent in 1990. Although Japan is perhaps an extreme example, these figures provide little evidence that the integration of Japanese and other ESEA country labor markets was achieved through labor mobility. Unfortunately, similar data are not available for other countries in ESEA
} 
Worker remittances are another mechanism through which national economies may become integrated. Remittances may be used to finance investments in human or physical capital or to increase consumption of domestically produced goods. Provided the net flows are from capital-rich to labor-rich countries, remittances will also promote factor price equalization, the hallmark of full integration. Nominal remittances increased for Filipino, Indonesian, and Thai workers worldwide at the modest rate of 6 percent per year from 1981 to 1991. This figure exceeds the 4.2 percent rate of increase in the number of those workers, but by less than the rate of price inflation, providing evidence of declining real remittances per migrant (assuming the average length of stay was stable during this period). Among Filipino, Indonesian, and Thai workers in Singapore, total remittances increased during 1981-91 at a rate of just 4 percent per year, well below the 25 percent rate of increase in the number of migrants. Thus, there is little evidence that worker remittances were an important mechanism of economic integration in ESEA during the 1980 s.

\section{B. Movements of Capital}

International capital mobility takes a variety of forms. It divides naturally into the mobility of public capital and the mobility of private capital. Public investment includes grants and loans from multilateral and bilateral organizations. Private investment includes direct foreign investments, whereby investors in one country acquire equity interests and direct managerial influence in enterprises located in another country. Private investment also includes investments in foreign financial instruments, such as stocks and bonds.

To gauge the extent of capital movements, we examine the amount of direct foreign investment from ESEA countries to countries within and outside the region. ${ }^{4}$ Table 3 reports

\footnotetext{
${ }^{4}$ Direct foreign investment is usually defined as total paid up shares of foreign subsidiaries that are owned by domestic companies (OECD 1994). Although data on the total amount of direct investment into ESEA are readily available, data on the sources of this investment are not. Portfolio investments would be a reasonable alternative indicator of private capital movements, but the source countries for these capital movements is even more difficult to ascertain.
} 
growth rates of intra and interregional direct foreign investment for ESEA's major capital-sending countries during the 1980 s, namely Hong Kong, Korea, Japan, Taiwan, and Singapore. Because data are not available for a consistent set of years, estimates are reported separately for each economy.

Direct foreign investment (DFI) from Japan, ESEA's dominant exporter of capital, increased at an average annual rate of 21 percent during 1980-92. The rate of increase accelerated in the mid-1980s, following the sharp appreciation of the yen against the dollar triggered by the 1985 Plaza Accord. Japan's DFI to other ESEA countries, which grew at an average annual rate of 15 percent from 1980-92, also accelerated in the mid-1980s. This acceleration is consistent with the view that yen appreciation led Japan to invest in lower-wage countries in ESEA in an attempt to remain competitive in international product markets.

For Hong Kong and Korea, the 1980s growth rates of DFI within ESEA were greater than outside ESEA. They were lower for Japan, Taiwan, and Singapore. With the exception of Korea, ESEA's share of DFI declined among all of ESEA's major capital-sending countries. Thus, capital mobility furthered ESEA's regional integration in the 1980s, but not as rapidly as it promoted ESEA's integration with the rest of the world.

Table 4 reports levels of foreign investment by Taiwan and Japan in the ESEA region, divided into capital movements to current capital-sending countries (Japan, Korea, Hong Kong, Singapore, and Taiwan) and to current capital-receiving countries (China, Indonesia, Malaysia, Philippines, and Thailand). The share of investment directed toward the capital-receiving countries rose from about 43 percent in the early and mid-1980s to 61 percent by the early 1990 s. This shift supports the "flying geese" description of capital investment in the region, according to which industry is dynamically relocated to suitable lower-wage economies to maintain international competitiveness (see Tang 1994). Further analysis is needed to assess whether this description also fits patterns of foreign investment among the newly industrializing economies, a "cascading" pattern of intraregional capital mobility. 


\section{Movement of Goods}

Table 5 documents the rapid growth of trade within ESEA and between ESEA and the rest of the world during the 1980s, by reporting growth rates of exports. The figures in the second column are average annual rates of growth of ESEA exports to different country groups during 1979-92. The third column shows growth rates of total exports from ESEA and non-ESEA countries. The reported growth rates are the coefficients of linear trend terms in simple regression models in which the dependent variable is the natural logarithm of the nominal value of exports (converted to U.S. dollars using period average market exchange rates).

Table 5 indicates that the current dollar value of ESEA's intraregional exports during 1979-92 grew at an average annual rate of 12.2 percent, about one-third faster than the 9.4 percent growth rate of ESEA's inter-regional exports, almost double the growth rate of exports from non-ESEA industrial countries (7.3 percent), and more than double the growth rate of exports from all non-ESEA countries (6.0 percent). Thus, in terms of trade growth, ESEA countries outperformed non-ESEA countries, with the growth of ESEA's intraregional trade outpacing the growth of its inter-regional trade, which implies even faster integration within ESEA than between ESEA and the rest of the world.

Table 6 looks at the growth of trade in terms of changes in its distribution among country groups. The first set of columns reports shares of ESEA exports. The second and third sets of columns present the shares of total world exports and world GNP for different regions. From 1979-81 to 1990-92, ESEA countries increased their share of world exports from 15 to 22 percent, outpacing the growth in their share of world GNP, which increased from 17 to 22 percent. Equally impressive was the growth in the share of ESEA exports going to ESEA countries during this same period: from 33 to 41 percent. ${ }^{5}$

\footnotetext{
${ }^{5}$ See Jha 1994 for an especially lucid and detailed analysis of the growth of intraregional trade in ESEA and south Asia.
} 
Table 7 reports the 1992 level and the 1979-92 growth rates of trade between ESEA countries. The growth rates are calculated using export data for the endpoints of the time interval. Although Japan is the region's dominant trading partner, China and Hong Kong have the largest country-to-country trade flow in ESEA. Overall, 61 percent of exports that stayed within ESEA in 1992 were accounted for by Japan (31 percent), Hong Kong (15 percent), and China (15 percent), with an additional 17 percent attributable to Taiwan ( 9 percent) and Korea ( 8 percent). The rapid growth of trade between Hong Kong and China and of exports from Japan to Hong Kong, Korea, and Taiwan account for 41 percent of the growth of intraregional trade.

\section{Accounting for Labor Market Integration in ESEA}

The foregoing analyses provide evidence that the mechanisms of labor mobility, capital mobility, and trade have all contributed to labor market integration in ESEA. The purpose of this section is to measure the overall pace of labor market integration and to assess the relative importance of each mechanism to the overall process. We do this by converting the amount of trade and capital mobility within ESEA into units of equivalent labor migration, an exercise that necessitates estimating: (a) the amount of labor mobility between all pairs of countries in ESEA that would replace actual flows of capital between the countries, in a way that accounts for differences between the length of the working life of capital and the duration of stay of labor migrants; and (b) the amount of labor services embodied in ESEA's intraregional trade. ${ }^{6}$

To calculate the labor migration equivalent of capital movements, we begin by estimating the ratio of total labor force to capital stock for each country (see table 8). Following Leamer (1982), the capital stock of a country is assumed to be the accumulated gross domestic investment

\footnotetext{
${ }^{6}$ An alternative method for calculating labor migration equivalents of capital mobility and trade involves assuming some production function and then using estimated parameters to map DFI and export values into labor equivalents. We did not adopt this approach in our analysis because of the difficulty involved in assembling estimates of the necessary parameters for the different countries within ESEA.
} 
since 1970, assuming an average ten-year life span for capital due to depreciation. ${ }^{7}$ As one might expect, table 8 indicates that the labor to capital ratios for Thailand and Indonesia are much higher than the ratios for Japan or Singapore, and that the ratios declined over time as more capital was accumulated while population levels stabilized. ${ }^{8}$

For the next stage of the exercise, we conduct the following thought experiment: If there are two countries, (relatively capital-rich) country A and (relatively labor-rich) country B, how much labor would need to flow from B to A to have the same amount of production as would result from a capital flow from $A$ to $B$ ? The answer is the number of labor migrants from country B that would have worked with the capital had it remained in country A. We estimate this number, that is, the labor mobility equivalent of a given capital inflow, under two assumptions. First, we assume that people's productivity depends on their location (the low estimate). Thus, workers migrating from country B to country A exhibit the productivity levels of country A's workers. In this case, we calculate the labor mobility equivalent of a capital inflow by multiplying a country's total capital exports by the labor to capital stock ratio of the capital-sending country. Under the second assumption (the high estimate), people's productivity is inherent to them. Now country B workers moving to country A will have the same productivity as they did in country B, because their productivity is a function of their education and other personal characteristics. With this assumption, the labor mobility equivalent calculation involves multiplying a country's total capital exports by the labor to capital stock ratio of the capital-receiving country. Both estimates are calculated as they provide an upper and lower bound for labor mobility equivalents.

The final step in this exercise involves accounting for the fact that capital is long-lived. Suppose, for example, that some piece of capital depreciates fully when it becomes $t$ years old and that it works with $\mathrm{n}$ people (for simplicity, in both the capital-receiving and capital-sending countries). In this example, the labor mobility equivalent of moving this piece of capital would be

\footnotetext{
${ }^{7}$ Because of a lack of data on gross domestic investment for Taiwan, we estimate Taiwan's capital stock from data on gross fixed capital formation. Gross domestic investment equals gross fixed capital formation plus changes in inventory.

${ }^{8}$ Investment figures for China are not available, so we assume that China's labor to capital ratio is the same as Indonesia (the most relatively labor abundant country).
} 
$\mathrm{n}$ workers per year, or $\mathrm{nt}$ workers over the $\mathrm{t}$ year life of the capital. We assume that $\mathrm{n}$ workers moving for each of $t$ years is the same as $n t$ workers moving for one year.

As we assume that capital has a ten-year life span and depreciates linearly, a unit of foreign direct investment can only be used to full capacity during its first year. By the next year, it will retain only a fraction of its full value, and even less of its value by the second year. Thus, one unit of capital moving to a country for ten years is equivalent to five $\left(5=\int_{0}^{10}(10-x) d x\right)$ units of capital moving to a country for one year. To complete the capital conversion, we multiply the labor mobility equivalent by five to express capital mobility in person-years of labor migration. ${ }^{9}$

To convert trade among ESEA countries to equivalent units of labor migration, we estimate the amount of labor embodied in exports, that is, the number of workers involved in producing exports. As mentioned earlier, instead of trading with a partner, a country could simply export the capital and labor necessary for production and produce the good in the country's trade partner. The number of workers contributing to the production of exports is estimated by finding the share of workers in the economy contributing to exports and multiplying this by the total labor force. Assuming the share of labor in gross national product (GNP) equals the share of labor in exports, the number of workers contributing to the export sector is simply the percentage of exports in total production times the total labor force:

$$
\text { Labor mobility equivalent of trade }=\frac{\text { value of exports }}{\text { GNP }} \times \text { total labor force }
$$

Table 9 reports our calculations of equivalent units of labor migration associated with intraregional trade and capital mobility in 1980 and 1991. The first row presents the documented number of migrants within ESEA multiplied by the number of years, on average, migrants reside

\footnotetext{
${ }^{9}$ Improving upon this calculation would require data on lagged numbers of ESEA's intercountry migrants, which are unfortunately not available.
} 
in the host country - four (low estimate) to six (high estimate) years. ${ }^{10}$ The labor mobility equivalents for capital and trade (as calculated above) are reported in the next two rows. Both calculations for converting capital flows to labor mobility equivalents are provided. The sum of total labor mobility equivalents is presented in the last row.

The estimates show that trade was overwhelmingly the largest contributor to labor market integration in ESEA throughout the 1980s. For example, trade embodies a labor flow that is one to two orders of magnitude greater than that embodied in direct foreign investment and direct labor movements. The results also show that capital mobility contributed more to regional labor market integration than did labor mobility.

The figures in table 9 also reveal that labor market integration increased sharply among ESEA countries in the 1980s. Nearly 9 percent of ESEA's labor force participated, either directly via labor mobility or indirectly via capital mobility or trade, in cross-national labor market transactions in 1991, up from just 5.2 percent in 1980

\section{Conclusions}

We have two main results to report: first, the 1980s saw rapid integration of the labor markets of ESEA countries; and second, the integration was achieved mainly through the sharp increase in intraregional trade, with a relatively small contribution from intraregional capital mobility and an even smaller contribution from direct labor mobility.

Notwithstanding the considerable integration of ESEA labor markets that has already occurred, the prospects for further integration are quite strong. Much of the regional integration that occurred within ESEA during the 1980s seems to go hand in glove with ESEA's integration

\footnotetext{
${ }^{10}$ These figures are based on discussions with Mr. Manola Abella at the ILO office in Geneva. Given the changing composition of labor migrants in the region, accurately estimating duration of stay is difficult. The four to six years range is based on the idea that it takes approximately this many years in order to recoup the investment of migration.
} 
with the rest of the world (also accomplished mainly through sharply rising trade and increased capital mobility). With the end of the Uruguay Round of the General Agreement on Tariffs and Trade and the establishment of the World Trade Organization, mutual trade barriers are likely to diminish, thereby promoting further expansion of trade.

If ESEA's historical response to growing extraregional demand for its goods and services continues, one may expect further integration within the region. Indeed, as table 10 shows, the integration ESEA achieved in the 1980s occurred in the presence of nonzero tariff barriers. The first column in table 10 presents anthan the rates index of tariff restrictions estimated by Lee (1993) for different countries. The estimates for the regional aggregates are simple averages of the Lee figures for countries within the region. Although some countries in ESEA did have large protection indexes, for example, Thailand (0.046) and the Philippines $(0.036)$, the region as a whole had a lower level of tariff restrictions than other regions. Similarly, in the second column, average tariff rates for ESEA countries were in general lower than the rates for African countries and about equal to those for Latin American countries. ${ }^{11}$

Corresponding to potential further reductions of trade barriers is the considerable scope for further capital market integration. Negative attitudes and other institutional deterrents to the movement of capital decreased during the 1980s. This point is documented by table 11, which describes important laws that ESEA countries have instituted regarding international capital movements. In all cases, recent country legislation provides for increased incentives to attract foreign investment and indicates that barriers to capital mobility have diminished significantly since the late 1980s. For example, China has slowly been phasing in legislation to allow greater domestic capital ownership by foreign-owned firms.

In contrast to capital mobility, there is no indication that ESEA countries are dissatisfied with their immigration or emigration flows or that changes in their immigration and emigration

\footnotetext{
${ }^{11}$ These arguments do not imply that reducing tariff barriers are a sufficient condition for promoting growth in the region. Indeed, Rodrik (1994) shows that some ESEA countries grew rapidly despite strong trade policy intervention by their governments.
} 
policies are likely. Tables 12 and 13 report information on governmental perceptions of and government policies regarding the level of migration in different ESEA countries. This information is based on official replies of governments to the United Nations Population Inquiries, which are conducted every few years. Table 12 reports governmental perceptions in 1983 and 1993. In 1983 only Thailand and Malaysia considered immigration levels "too high," while all the other countries considered immigration flows to be at a "satisfactory" level. However, by 1993, only Indonesia perceived that the level of immigration had worsened, while the other countries either did not change their attitude or thought that the situation had improved. Similarly, we see that most countries believed that the level of emigration had become more "satisfactory" by 1993

Table 13 summarizes ESEA policies toward the level of migration. In 1983 all the ESEA countries were content with their immigration policies and were willing to "maintain" the level of immigration, while by 1993 three countries wished to "lower" immigration. Conversely, for emigration policies fewer countries wanted to "raise" emigration levels in 1993 compared to 1983. Both tables 12 and 13 seem to indicate that we may reasonably expect cross-country migrant labor flows to continue at about the same pace for the next decade. Thus, trade will likely continue as the main driving force behind integration, followed by capital mobility (which may increase in importance), and then by labor mobility.

Further declines in the costs of international transportation and communication and the increased prominence of integrative economic institutions within the region, such as the AsiaPacific Economic Cooperation, are likely to promote further integration. Also, given its economic position and geographic proximity to ESEA, Australia is likely to become more integrated with the ESEA countries, a development that has already begun. Table 14 shows that Australia's exports to ESEA countries (8.2 percent) grew at almost twice the rate of Australia's trade with the rest of the world (4.6 percent) during 1979-92. Similarly, Australia's imports from ESEA countries also grew at a rate almost 1.5 times as large as its imports from the rest of the world. 


\section{References}

Abella, Manolo, and Hiromi Mori. 1994. "Structural Change and Labour Migration in East Asia." Paper presented at the OECD Conference on Development Systems, Employment, and International Migration, July 11-13, Paris.

Athukorala, Premachandra. 1993. "Statistics on Asian Labour Migration: Review of Sources, Methods and Problems." In ILO and Asian Regional Team for Employment Promotion, eds., International Labour Migration Statistics and Information Networking in Asia. New Delhi, India: ILO.

Baldwin, Robert E. 1995. "The Effects of Trade and Foreign Direct Investment on Employment and Relative Wages," National Bureau of Economic Research Working Paper No. 5037. Cambridge, Massachusetts: NBER.

Bloom, David E., and Adi Brender. 1993. "Labor and the Emerging World Economy." Population Bulletin 48 (2). Washington DC: Population Reference Bureau, Inc.

Borjas, George J. 1990. Friends or Strangers. New York: Basic Books.

Chaponniere, J.R. 1992. "The Newly Industrialising Economies of Asia: International Investment and Transfer of Technology." STI Review (April).

Chen, E.K.Y. 1992. "Changing Pattern of Financial Flows in the Asia-Pacific Region and Policy Responses." Asian Development Review 10 (1): 46-85.

Chen, E.K.Y. 1993. "Foreign Direct Investment in East Asia." Asian Development Review 11 (1): 24-59.

Ehrenberg, Ronald G. 1994. Labor Markets and Integrating National Economies. Washington, D.C.: Brookings Institution.

Erzan, Refik, and Guy Karsenty. 1989. "The Profile of Protection in Developing Countries." UNCTAD Review 1 (1): $51-74$.

Feldstein, M. and Charles Horioka. 1980. "Domestic Saving and International Capital Flows." Economic Journal 90 (June): 314-29.

Frankel, Jeffrey A. 1984. "International Capital Mobility and Crowding Out in the US Economy: Imperfect Integration of Financial Markets or of Goods Markets?" National Bureau of Economic Research Working Paper No. 1772. Cambridge, Massachusetts: NBER.

Gereffi, Gary. 1995. "Global Commodity Chains and Third World Development." Paper presented at a conference organized by the International Institute for Labour Studies and the ILO Regional Office for Asia and the Pacific, Bangkok, Thailand. January 23-26.

Haque, N. and P.J. Montiel. 1991. "Capital Mobility in Developing Countries: Some Empirical Tests." World Development 10 (10): 1391-98.

ILO (International Labour Organisation). 1992. World Labour Report. Geneva: ILO. 
Asian Regional Program on Labor Migration. 1993. "Newspaper Clippings and Reprints of Periodicals", May. Bangkok: ILO.

IMF (International Monetary Fund). Various years. Direction of Trade Statistics Yearbook. Washington D.C.: IMF.

Jha, Satish C. 1994. "Intraregional Trade in Asia: Current Trends and Prospects." Paper presented at 1994 Financial Times Conference on the Asian Capital Markets, London, April 28-29.

Leamer, Edward E. 1982. Sources of International Comparative Advantage: Theory and Evidence. Cambridge, Massachusetts: MIT Press.

Lee, Jong-Wha. 1993. "International Trade, Distortions and Long-run Economic Growth," IMF Staff Papers (June). Washington, D.C.: International Monetary Fund.

Lim, Linda, et. al. 1992. Foreign Direct Investment and Industrialisation in Malaysia, Singapore, Taiwan and Thailand. Development Studies Center, Paris: OECD.

Macmillen, M.J. 1982. "The Economic Effects of International Migration: A Survey," Journal of Common Market Studies XX (3): 245-67.

Mishkin, Frederick. 1984. “Are Real Interest Rates Equal Across Countries? An Empirical Investigation of International Parity Conditions." Journal of Finance 39: 1345-58.

Montiel, P.J. 1994. "Capital Mobility in Developing Countries: Some Measurement Issues and Empirical Estimates." The World Bank Economic Review, 8 (3): 245-67.

Obstfeld, Maurice. 1986. "How Integrated Are Capital markets? Some New Tests." National Bureau of Economic Research Working Paper No. 2075. Cambridge, Massachusetts: NBER.

OECD (Organization for Economic Cooperation and Development). 1993. Foreign Direct Investment Relations between the OECD and the Dynamic Asian Economies. Paris: OECD.

communication for Japan between 1980-81.

Razin, Asad, and Efraim Sadka. 1992. "International Migration and International Trade." National Bureau of Economic Research Working Paper No. 4230. Cambridge, Massachusetts: NBER.

Riedel, James. 1992. "Intra-Asian Trade and Foreign Direct Investment." Asian Development Review 10 (2): 111-46.

Rodrik, Dani. 1994. "King Kong Meets Godzilla: The World Bank and the East Asian Miracle." Draft. New York, NY: Columbia University.

Ruffin, Roy J. 1993. "The Role of Foreign Investment in the Economic Growth of the Asian and Pacific Region." Asian Development Review 11 (1): 1-23. 
Stark, Oded. 1991. The Migration of Labor. Cambridge, Massachusetts: Basil Blackwell.

Taiwan Council for Economic Planning and Development. 1994. Taiwan Statistical Data Book, 1994. Republic of China.

Taiwan Investment Commission, Ministry of Economic Affairs. Various years. Statistics on Overseas Chinese \& Foreign Investment. Republic of China.

Tang, Min. 1994. "Recent Development on Capital Flows to the Asian and Pacific Developing Countries." Manilla, Philippines: Asian Development Bank. Draft.

Tang, Min, and Myo Thant. 1995. "Growth Triangles in International Perspective." Paper presented at a conference organized by the International Institute for Labour Studies and the ILO Regional Office for Asia and the Pacific, Bangkok, Thailand. January 23-26.

Teal, Gregory. 1995. "The JSR (Johor-Singapore-Riau) Growth Triangle." Paper presented at a conference organized by the International Institute for Labour Studies and the ILO Regional Office for Asia and the Pacific, Bangkok, Thailand. January 23-26.

Thant, Myo, Min Tang, and Hiroshi Kakazu. 1994. Growth Triangles in Asia. Hong Kong: Oxford University Press.

The Central Bank of China, Taiwan. Various years. Financial Statistics

Union of International Associations. 1994. Yearbook of Organizations, vol. 1 Organization Descriptions and Cross-References. Munich: K.G. Saur.

United Nations Development Programme (UNDP) /ILO Asian Regional Programme on International Labour Migration. 1993. Regional Seminar on International Labour Migration Statistics and Information Networking in Asia: Summary of Proceedings. New Delhi, India: ILO.

UN (United Nations). 1992a. World Investment Directory 1992: Foreign Direct Investment, Legal Framework and Corporate Data, Vol. 1 Asia and the Pacific. New York.

\section{Database, 1991. New York.}

Population Monitoring Report. New York.

, Department of International Economic and Social Affairs. 1989. Trends in Population
Policy, Population Studies. No. 114. New York.

World Bank. 1994. World Tables. Baltimore, Maryland: Johns Hopkins University Press.

1995. World Development Report 1995. Washington, D.C. Draft.

Yue, C.S. 1993. "Foreign Direct Investment in ASEAN Economies." Asian Development Review 11 (1): 60-102. 
Table 1: Level and Growth of Outmigration from ESEA's Major Labor Sending Countries by Destination Region, 1980 - 91 (percent)

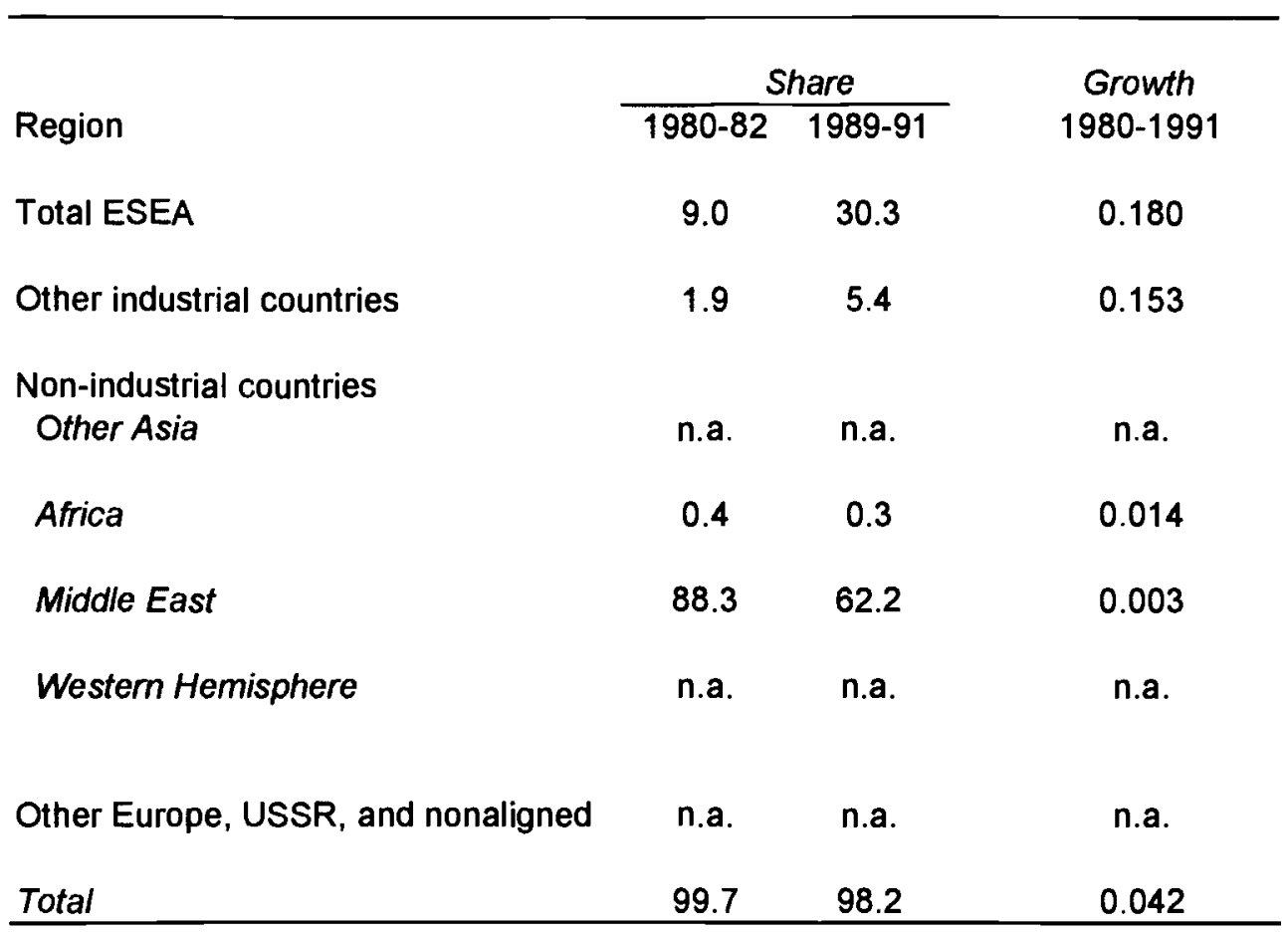

Note: Only the major labor-sending countries of the region are included (Indonesia, Philippines, Thailand, and Korea).

The growth rates are slope coefficients from regression equations of the following form: $\log X_{t}=\alpha_{0}+\alpha_{1} t$, where $X_{t}$ is the number of migrants for the relevant regional grouping in year $t$.

All numbers are in percents. The shares may add to less than 1 because of migration to non-specified areas.

Because of a lack of consistent data for the entire time period, three of the regions have been combined. All countries in Asia are contained in ESEA. Countries in both the Western Hemisphere and Other Europe are included in the Other Industrial Countries category, and countries in Sub-Saharan Africa are included in the Middle East category. The term "n.a." reflects this agglomeration.

Source: ILO (1990) and personal correspondence with the Bangkok Office of the ILO. 
Table 2: Outmigrants from Indonesia, the Philippines, and Thailand, by Destination Country/ Region, 1991

\begin{tabular}{|c|c|c|c|c|c|c|}
\hline \multirow[b]{2}{*}{ Region } & \multicolumn{2}{|c|}{ Indonesia } & \multicolumn{2}{|c|}{ Philippines } & \multicolumn{2}{|c|}{ Thailand } \\
\hline & Number & Share (\%) & Number & Share (\%) & Number & Share (\%) \\
\hline Total ESEA & 53,224 & 42.2 & 121,843 & 26.4 & 29,172 & 47.8 \\
\hline China & 1 & & - & & 134 & \\
\hline Hong Kong & 1,079 & & 50,652 & & 8,431 & \\
\hline Indonesia & n.a. & & - & & 146 & \\
\hline Japan & 873 & & 57,344 & & 6,263 & \\
\hline Korea & 426 & & 193 & & - & \\
\hline Malaysia & 40,715 & & 5,741 & & 2,473 & \\
\hline Philippines & - & & n.a. & & - & \\
\hline Singapore & 9,937 & & 7,697 & & 9,488 & \\
\hline Taiwan & 190 & & 43 & & 2,237 & \\
\hline Thailand & 3 & & 173 & & n.a. & \\
\hline Other industrial countries & 4,645 & 3.7 & 26,529 & 5.8 & 3,227 & 5.3 \\
\hline \multicolumn{7}{|l|}{ Non-industrial countries } \\
\hline Other Asia & 1,474 & 1.2 & 10,112 & 2.2 & 8,877 & 14.6 \\
\hline Africa & 17 & 0.0 & - & - & 35 & 0.1 \\
\hline Middle East & 66,884 & 53.0 & 302,825 & 65.6 & 19,660 & 32.2 \\
\hline Western Hemisphere & - & - & - & - & - & - \\
\hline Other Europe, USSR, and nonaligned & 1 & 0.0 & - & - & - & - \\
\hline Total & 126,245 & 100.0 & 461,309 & 100.0 & 60,971 & 100.0 \\
\hline
\end{tabular}

Note: For Thailand, the migration to Libya and Algeria are included in the Middle East region. "-" indicates that no migration was reported to this destination.

"n.a." means not applicable.

Source: ILO Bangkok Office. 
Table 3: Distribution and Growth of Direct Foreign Investment among ESEA's Major Capital-Sending Countries by Destination Region, circa $1980-90$

\begin{tabular}{|c|c|c|c|c|c|c|c|c|c|}
\hline \multirow[b]{3}{*}{ Region } & \multicolumn{3}{|c|}{ Hong Kong } & \multicolumn{3}{|c|}{ Korea } & \multicolumn{3}{|c|}{ Japan } \\
\hline & \multicolumn{2}{|c|}{ Shares (\%) } & \multirow{2}{*}{$\frac{\text { Growth }}{1984-89}$} & \multicolumn{2}{|c|}{ Shares $(\%)$} & \multirow{2}{*}{$\frac{\text { Growth }}{1981-90}$} & \multicolumn{2}{|c|}{ Shares $(\%)$} & \multirow{2}{*}{$\frac{\text { Growth }}{1980-92}$} \\
\hline & $1984-86$ & $1987-89$ & & $1981-83$ & $1988-90$ & & $1980-82$ & $1990-92$ & \\
\hline Rest of world & 32.5 & 40.6 & 0.102 & 83.5 & 69.0 & 0.287 & 72.7 & 85.8 & 0.224 \\
\hline \multirow[t]{3}{*}{ World total } & 100.0 & 100.0 & 0.267 & 100.0 & 100.0 & 0.302 & 100.0 & 100.0 & 0.209 \\
\hline & \multicolumn{3}{|c|}{ Taiwan } & \multicolumn{3}{|c|}{ Singapore } & & & \\
\hline & \multicolumn{2}{|c|}{ Shares (\%) } & Growth & \multicolumn{2}{|c|}{ Shares (\%) } & Growth & & & \\
\hline Region & $1980-82$ & $1990-92$ & $\overline{1980-92}$ & $1980 \overline{-82}$ & $1987-89$ & $\overline{1980-89}$ & & & \\
\hline Total ESEA & 70.0 & 70.3 & 0.119 & 73.3 & 61.4 & 0.041 & & & \\
\hline Rest of world & 30.0 & 29.7 & 0.163 & 26.7 & 38.6 & 0.127 & & & \\
\hline World total & 100.0 & 100.0 & 0.126 & 100.0 & 100.0 & 0.068 & & & \\
\hline
\end{tabular}

Note: Only major capital exporters are included in the data (Hong Kong, Korea, Japan, Taiwan, and Singapore).

The growth rates are slope coefficients from regression equations of the following form: $\log X_{t}=\alpha_{0}+\alpha_{1} t$, where $X_{t}$ is the amount of foreign investment for the relevant regional grouping in year $t$.

Source: Japan: OECD (various years); Korea, Singapore, Hong Kong: OECD (1993); Taiwan: Ministry of Economic Affairs (various years). 
Table 4: Total Foreign Investment by Japan and Taiwan in ESEA, Selected Years

\begin{tabular}{|c|c|c|c|c|}
\hline \multirow[b]{2}{*}{ Region } & \multicolumn{2}{|c|}{$1983-85$} & \multicolumn{2}{|c|}{$1990-92$} \\
\hline & $\begin{array}{c}\text { Amount } \\
\text { (US\$ millions) }\end{array}$ & $\begin{array}{c}\text { Share } \\
(\%)\end{array}$ & $\begin{array}{c}\text { Amount } \\
\text { (US } \$ \text { millions) }\end{array}$ & $\begin{array}{l}\text { Share } \\
(\%)\end{array}$ \\
\hline $\begin{array}{l}\text { To ESEA's capital-sending countries } \\
\text { (Japan, Hong Kong, Korea } \\
\text { Singapore, Taiwan) }\end{array}$ & 2,691 & 55.2 & 7,632 & 39.2 \\
\hline $\begin{array}{l}\text { To ESEA's capital-receiving countries } \\
\text { (China, Indonesia, Malaysia } \\
\text { Philippines, Thailand) }\end{array}$ & 2,183 & 44.8 & 11,831 & 60.8 \\
\hline Total & 4,874 & 100.0 & 19,463 & 100.0 \\
\hline
\end{tabular}

Source: Japan: OECD (various years); Taiwan: Ministry of Economic Affairs (various years). 
Table 5: Growth Rates of Exports, 1979-92

\begin{tabular}{lcc}
\hline Region & ESEA exports to & World exports from \\
Total ESEA & 0.122 & 0.104 \\
Rest of world & 0.094 & 0.060 \\
Total & 0.104 & 0.068 \\
\hline
\end{tabular}

Note: The growth rates are slope coefficients from regression equations of the following form: $\log X_{t}=\alpha_{0}+\alpha_{1} t$, where $X_{t}$ is the nominal value of exports for the relevant regional grouping in year $t$.

Source: IMF (various years); Taiwan Council for Economic Planning and Development (1994). 
Table 6: The Distribution of ESEA Exports and World Exports by Region, 1979-92 (percent)

\begin{tabular}{lcc|cc|ccc}
\hline & \multicolumn{2}{c|}{ ESEA exports to } & \multicolumn{2}{c|}{ World exports from } & \multicolumn{2}{c}{ Share of world GNP } \\
Region & $\underline{1979-81}$ & $\underline{1990-92}$ & $\underline{1979-81}$ & $\underline{1990-92}$ & $\underline{1979-81}$ & $\underline{1990-92}$ \\
Total ESEA & 32.9 & 41.0 & 14.7 & 21.8 & 16.9 & 22.2 \\
Other industrial countries & 42.9 & 46.9 & 58.4 & 61.3 & 66.1 & 63.1 \\
Other non-industrial Asia & 4.1 & 2.8 & 1.1 & 3.2 & 2.1 & 1.7 \\
All other countries & 18.8 & 8.8 & 25.7 & 13.8 & 14.8 & 13.1 \\
\hline
\end{tabular}

Note: The sum of the shares is less than 1 because of trade to nonspecified areas.

Source: IMF (various years); Taiwan Council for Economic Planning and Development (1994); World Bank (1994). 
Table 7: Levels (1992) and Average Annual Growth Rates (1979-92) of Trade within ESEA

\begin{tabular}{|c|c|c|c|c|c|c|c|c|c|c|}
\hline \multirow{3}{*}{$\begin{array}{l}\text { TO: } \\
\text { Chine }\end{array}$} & \multicolumn{10}{|c|}{ EXPORTS FROM: } \\
\hline & China & Hong Kong & Indonesia & Japan & Korea & Malaysia $F$ & Philippines & Singapore & Taiwan & Thailand \\
\hline & - & $\begin{array}{c}35,412 \\
(41.7 \%)\end{array}$ & $\begin{array}{c}1,613 \\
(62.0 \%)\end{array}$ & $\begin{array}{c}11,967 \\
(9.5 \%)\end{array}$ & $\begin{array}{c}2,654 \\
(76.0 \%)\end{array}$ & $\begin{array}{c}772 \\
(11.8 \%)\end{array}$ & $\begin{array}{c}146 \\
(8.4 \%)\end{array}$ & $\begin{array}{c}1,124 \\
(15.6 \%)\end{array}$ & $\begin{array}{l}\text { n.a. } \\
\text { n.a. }\end{array}$ & $\begin{array}{r}386 \\
(13.2 \%)\end{array}$ \\
\hline Hong Kong & $\begin{array}{l}37,464 \\
(20.5 \%)\end{array}$ & - & $\begin{array}{c}869 \\
(18.2 \%)\end{array}$ & $\begin{array}{l}20,779 \\
(14.3 \%)\end{array}$ & $\begin{array}{c}5,909 \\
(20.4 \%)\end{array}$ & $\begin{array}{c}1,549 \\
(17.6 \%)\end{array}$ & $\begin{array}{c}426 \\
(7.9 \%)\end{array}$ & $\begin{array}{c}4,591 \\
(12.8 \%)\end{array}$ & $\begin{array}{c}15,415 \\
(22.2 \%)\end{array}$ & $\begin{array}{c}1,507 \\
(14.5 \%)\end{array}$ \\
\hline Indonesia & $\begin{array}{c}471 \\
(29.6 \%)\end{array}$ & $\begin{array}{c}734 \\
(5.2 \%)\end{array}$ & - & $\begin{array}{l}5,582 \\
(7.8 \%)\end{array}$ & $\begin{array}{c}1,935 \\
(19.3 \%)\end{array}$ & $\begin{array}{c}506 \\
(6.1 \%)\end{array}$ & $\begin{array}{c}40 \\
-(1.1 \%)\end{array}$ & $\begin{array}{l}\text { n.a. } \\
\text { n.a. }\end{array}$ & $\begin{array}{l}1,215 \\
(8.9 \%)\end{array}$ & $\begin{array}{c}283 \\
(3.1 \%)\end{array}$ \\
\hline Japan & $\begin{array}{l}11,691 \\
(11.7 \%)\end{array}$ & $\begin{array}{c}6,262 \\
(14.9 \%)\end{array}$ & $\begin{array}{c}11,607 \\
(3.8 \%)\end{array}$ & - & $\begin{array}{c}11,599 \\
(10.0 \%)\end{array}$ & $\begin{array}{l}5,401 \\
(5.8 \%)\end{array}$ & $\begin{array}{l}2,020 \\
(4.0 \%)\end{array}$ & $\begin{array}{l}2,813 \\
(5.7 \%)\end{array}$ & $\begin{array}{c}8,894 \\
(11.2 \%)\end{array}$ & $\begin{array}{c}5,686 \\
(13.3 \%)\end{array}$ \\
\hline Korea & $\begin{array}{c}2,435 \\
(137.1 \%)\end{array}$ & $\begin{array}{c}1,938 \\
(18.9 \%)\end{array}$ & $\begin{array}{c}1,385 \\
(10.4 \%)\end{array}$ & $\begin{array}{c}17,786 \\
(8.4 \%)\end{array}$ & - & $\begin{array}{c}1,389 \\
(15.5 \%)\end{array}$ & $\begin{array}{c}27 \\
-(12.0 \%)\end{array}$ & $\begin{array}{c}1,626 \\
(16.2 \%)\end{array}$ & $\begin{array}{c}1,150 \\
(15.8 \%)\end{array}$ & $\begin{array}{r}533 \\
(19.9 \%)\end{array}$ \\
\hline Malaysia & $\begin{array}{c}645 \\
(10.8 \%)\end{array}$ & $\begin{array}{c}832 \\
(13.8 \%)\end{array}$ & $\begin{array}{c}534 \\
(17.4 \%)\end{array}$ & $\begin{array}{c}8,128 \\
(13.9 \%)\end{array}$ & $\begin{array}{c}1,136 \\
(22.0 \%)\end{array}$ & - & $\begin{array}{c}208 \\
(10.5 \%)\end{array}$ & $\begin{array}{l}5,699 \\
(8.2 \%)\end{array}$ & $\begin{array}{l}\text { n.a. } \\
\text { n.a. }\end{array}$ & $\begin{array}{r}842 \\
(10.4 \%)\end{array}$ \\
\hline Philippines & $\begin{array}{r}209 \\
(3.4 \%)\end{array}$ & $\begin{array}{c}1,108 \\
(11.5 \%)\end{array}$ & $\begin{array}{c}176 \\
(0.5 \%)\end{array}$ & $\begin{array}{l}3,520 \\
(6.2 \%)\end{array}$ & $\begin{array}{c}746 \\
(15.8 \%)\end{array}$ & $\begin{array}{c}477 \\
(7.6 \%)\end{array}$ & - & $\begin{array}{r}684 \\
(8.5 \%)\end{array}$ & $\begin{array}{c}1,023 \\
(13.3 \%)\end{array}$ & $\begin{array}{r}155 \\
(22.1 \%)\end{array}$ \\
\hline Singapore & $\begin{array}{c}2,029 \\
(15.9 \%)\end{array}$ & $\begin{array}{c}3,130 \\
(13.0 \%)\end{array}$ & $\begin{array}{l}2,878 \\
(3.0 \%)\end{array}$ & $\begin{array}{c}12,981 \\
(13.0 \%)\end{array}$ & $\begin{array}{c}3,222 \\
(24.0 \%)\end{array}$ & $\begin{array}{c}9,391 \\
(12.9 \%)\end{array}$ & $\begin{array}{c}251 \\
(10.9 \%)\end{array}$ & - & $\begin{array}{c}2,876 \\
(15.9 \%)\end{array}$ & $\begin{array}{r}2,823 \\
(15.1 \%)\end{array}$ \\
\hline Taiwan & $\begin{array}{l}\text { n.a. } \\
\text { n.a. }\end{array}$ & $\begin{array}{c}4,219 \\
(18.1 \%)\end{array}$ & $\begin{array}{c}1,345 \\
(12.6 \%)\end{array}$ & $\begin{array}{l}21,166 \\
(13.0 \%)\end{array}$ & $\begin{array}{c}2,262 \\
(22.5 \%)\end{array}$ & $\begin{array}{c}1,270 \\
(15.6 \%)\end{array}$ & $\begin{array}{c}283 \\
(11.4 \%)\end{array}$ & $\begin{array}{c}1,545 \\
(16.7 \%)\end{array}$ & - & $\begin{array}{r}618 \\
(18.6 \%)\end{array}$ \\
\hline Thailand & $\begin{array}{c}893 \\
(11.7 \%)\end{array}$ & $\begin{array}{c}1,059 \\
(15.0 \%)\end{array}$ & $\begin{array}{c}335 \\
(18.5 \%)\end{array}$ & $\begin{array}{c}10,384 \\
(14.9 \%)\end{array}$ & $\begin{array}{c}1,532 \\
(22.3 \%)\end{array}$ & $\begin{array}{c}1,490 \\
(19.4 \%)\end{array}$ & $\begin{array}{c}109 \\
(14.4 \%)\end{array}$ & $\begin{array}{c}2,700 \\
(12.1 \%)\end{array}$ & $\begin{array}{c}1,810 \\
(19.1 \%)\end{array}$ & - \\
\hline
\end{tabular}

Note: The growth rate from 1979-1992 is reported in parentheses below the 1992 level of exports in millions of current U.S. dollars. The growth rate is calculated as the average percentage increase in export value from 1979 to 1992 . The rate is calculated since 1980 for Korean exports to China, Malaysian exports to Philippines, and Chinese exports to Indonesia; since 1981 for Indonesian Exports to China; and since 1990 for Chinese Exports to Korea, because exports were not reported for these pairs in 1979.

"n.a." indicates these countries did not report exports to the respective partner countries from $1979-1992$.

" - " means not applicable.

Source: IMF (various years); Taiwan Council for Economic Planning and Development (1994). 
Table 8: Ratio of Total Labor Force to Total Capital Stock in ESEA, Selected Years (workers / US $\$ 1,000,000)$

\begin{tabular}{lrrr}
\hline Country & 1980 & 1986 & $\underline{1991}$ \\
\cline { 2 - 3 } China & 881 & 519 & 429 \\
Hong Kong & 88 & 62 & 36 \\
Indonesia & 881 & 519 & 429 \\
Japan & 42 & 29 & 14 \\
Korea, Republic of & 206 & 127 & 54 \\
Malaysia & 223 & 131 & 116 \\
Philippines & 491 & 498 & 518 \\
Singapore & 64 & 32 & 22 \\
Taiwan & 127 & 118 & 59 \\
Thailand & 745 & 549 & 234 \\
\hline
\end{tabular}

Note: For Taiwan gross fixed capital formation was used instead of gross domestic investment.

Data on China's investment patterns is not available so we assume that the ratios are similar to Indonesia (the most labor abundant country).

Source: Taiwan Council for Economic Planning and Development (1994); World Bank (1994). 
Table 9: ESEA Labor, Capital, and Trade Movements in Units of Labor Mobility Equivalents, Selected Years (person-years)

\begin{tabular}{|c|c|c|c|c|}
\hline \multirow[b]{3}{*}{ I. Low estimate } & \multicolumn{2}{|c|}{1980} & \multicolumn{2}{|c|}{1991} \\
\hline & Number & Share (\%) & Number & Share $(\%)$ \\
\hline & & & & \\
\hline Labor migration & 95,672 & 0.28 & 937,588 & 1.17 \\
\hline Capital movements & 525,377 & 1.55 & 466,107 & 0.58 \\
\hline Trade & $33,327,383$ & 98.17 & $78,826,249$ & 98.25 \\
\hline Total & $33,948,431$ & & $80,229,944$ & \\
\hline \multicolumn{5}{|l|}{ II. High estimate } \\
\hline Labor migration & 143,508 & 0.33 & $1,406,382$ & 1.62 \\
\hline Capital movements & $9,904,695$ & 22.83 & $6,488,935$ & 7.48 \\
\hline Trade & $33,327,383$ & 76.83 & $78,826,249$ & 90.90 \\
\hline Total & $43,375,585$ & & $86,721,566$ & \\
\hline Labor force of ESEA & $731,865,936$ & & $917,211,180$ & \\
\hline GNP per capita of ESEA (US\$) & 1,208 & & 2,828 & \\
\hline
\end{tabular}

Source: Author's calculations. 


\section{Table 10: Measure of Tariff Restrictions}

\begin{tabular}{lcc}
\hline Region & Lee index & $\begin{array}{c}\text { Average tariff rates } \\
\text { (percent) }\end{array}$ \\
\cline { 2 - 3 } Total ESEA & n.a. & n.a. \\
China & 0.000 & 0.2 \\
Hong Kong & 0.016 & 32.6 \\
Indonesia & 0.003 & 4.0 \\
Japan & 0.029 & 23.5 \\
Korea & 0.015 & 25.0 \\
Malaysia & 0.036 & 29.2 \\
Philippines & 0.005 & 6.4 \\
Singapore & 0.018 & 22.8 \\
Taiwan & 0.046 & 30.7 \\
Thailand & & \\
& 0.010 & n.a. \\
Other industrial countries & & \\
Non-industrial countries & & n.a. \\
Other Asia & 0.057 & 30.5 \\
Africa & 0.038 & 7.0 \\
Middle East & 0.029 & 24.3 \\
Western Hemisphere & 0.036 & n.a. \\
Other Europe, USSR, and nonaligned & & \\
\hline
\end{tabular}

Note: The Lee index is calculated by making the following calculation:

Tariff Restriction $=[.528-.026 * \log ($ AREA $)-.096 \log (\mathrm{DIST})]{ }^{*} \log (1+$ OWTI)

where AREA $=$ size of the country, DIST $=$ average distance to capitals of the world's twenty major exporters, and OWTI $=$ own import weighted tariff rates on intermediate inputs and capital goods.

The aggregate measures are calculated by taking the average of the country rates in the region.

Source: The Lee index of tariff restrictions is calculated in Lee (1993) and is part of the Barro-Lee dataset available from the National Bureau of Economic Research in Cambridge, Massachusetts. The average tariff rate figures for ESEA are from Riedel (1992), while the regional aggregates are from Erzan and Karsenty (1989). The rates for the regions are based on a sample of countries in the region. 


\section{Table 11: Foreign Investment Constraints for ESEA}

China

Ministry of Foreign Economic Relations and Trade

Laws: Law of China on Joint Ventures using Chinese and Foreign Investment of August 8, 1979, as amended by the Law on Chinese-Foreign Equity Joint Ventures of April 4, 1990.

Efforts geared to rely gradually on market mechanisms and give enterprises operative and managerial control. In particular, the 1990 amendment increased investors' flexibility in management and exchange control and foresaw the possibility of indefinite investment periods for some joint ventures.

Law on Wholly Foreign-Owned Enterprise of December 4, 1986.

Network of special economic zones enjoying investment privileges. Different incentives granted to productive ventures, decentralization of the administrative process regarding foreign investment, and simplification of the approval procedures.

Law of the P.R. of China on Chinese-Foreign Cooperative Joint Ventures of April 13, 1988.

Salient features: The investment contributed by foreign participants shall generally not be less than 25 percent. For equity and cooperative joint ventures, the establishment of a legal entity determines its civil liability limited to the property owned by the venture. Wholly-owned enterprises covered by the law of 1986 , however, are not considered as "limited" liability companies.

\section{Korea}

Ministry of Finance

Laws: Foreign Capital Inducement Act No. 3691 of December 12, 1993. Presidential Decree No. 12475 of July 1, 1988 enforcing the above act. Working Rules for the Implementation of the above Act. Ordinance No. 1753 of July 1, 1988.

Salient features: Introduced a negative list system and eased approval procedures. Liberalized the capital market and policies toward imports.

\section{Sinqapore}

Economic Development Board

Laws: Economic Expansion Incentives (Relief from Income Tax) Act 1967 as amended and revised up to 1985

Salient features: Promoting and supporting high technology industries. Service orientation; Singapore to become an international business center by encouraging TNCs to establish their regional headquarters there.

\section{Taiwan}

Investment Committee (Ministry of Foreign Affairs)

Laws: Statute for Encouragement of Investment 1960 as last amended on January 26, 1987.

Salient features: Tax holidays, tax reductions, and financial support are offered to foreign investors. Export processing zones offer additional incentives and an independent administration system. 


\section{Table 11: Foreign Investment Constraints for ESEA (cont.)}

\section{Indonesia}

Capital Investment Coordinating Board except in the energy and financial sectors

Laws: December Package 1987 (Seven Decrees: Decisions Regulations).

Salient features: Easing of investment regulations, and introduction of a negative list system. Gradually opening more sectors to FDI and reducing public investment in favor of private investment.

\section{Malarsia}

Malaysian Industrial Development Authority

Laws: Promotion of Investment Act 327 of 1986 as amended by Act A656 of 1986. Investment Regulation No. 410 of 1988

Salient features: The preferred sectors are manufacturing, agriculture, and tourism. In terms of foreign equity ownership, Malaysia has become more flexible: foreigners may hold 80 percent of projects that export at least 80 percent of output. A higher percentage of wholly-foreign ownership is allowed upon approval.

\section{Philippines}

Board of Investment

Laws: Executive Order No. 226 implementing the Omnibus Investment Code 1987.

Salient features: Government regulates the establishment of foreign investments when foreign equity exceeds 30 percent. For firms located in export processing zones, a wide range of incentives are provided. Lessening of restrictions on FDI in protected industries.

\section{Thailand}

Board of Investment

Laws: Promotion of Investment Act of 1977.

Salient features: The main task of the Board is to encourage private investment in priority areas. Foreign Direct Investment is encouraged to complement local business and to encourage the transfer of technology. Projects to be given special consideration by the Board include those that strengthen domestic output growth through exports, increase employment, and promote regional development.

Source: United Nations (1992a). 
Table 12: Governmental Perceptions of the Level of Migration, ESEA: 1983 versus 1993

\begin{tabular}{|c|c|c|c|c|c|c|}
\hline \multirow[b]{3}{*}{ Country } & \multicolumn{6}{|c|}{ IMMIGRATION } \\
\hline & \multicolumn{3}{|c|}{ Perceptions in 1983} & \multicolumn{3}{|c|}{ Perceptions in 1993} \\
\hline & Too Low & Satisfactory & Too High & Too Low & Satisfactory & Too High \\
\hline China & & $x$ & & & $x$ & \\
\hline Indonesia & & $x$ & & & & $x$ \\
\hline Japan & & $x$ & & & $x$ & \\
\hline Korea, Rep. of & & $x$ & & & $x$ & \\
\hline Malaysia & & & $\mathbf{x}$ & & $x$ & \\
\hline Philippines & & $\mathbf{x}$ & & & $\mathbf{x}$ & \\
\hline Singapore & & $x$ & & & $\mathbf{x}$ & \\
\hline Thailand & & & $x$ & & $x$ & \\
\hline
\end{tabular}

\begin{tabular}{|c|c|c|c|c|c|c|}
\hline \multirow[b]{3}{*}{ Country } & \multicolumn{6}{|c|}{ EMIGRATION } \\
\hline & \multicolumn{3}{|c|}{ Perceptions in 1983} & \multicolumn{3}{|c|}{ Perceptions in 1993} \\
\hline & Too Low & Satisfactory & Too High & Too Low & Satisfactory & Too High \\
\hline China & & $x$ & & & $\mathbf{x}$ & \\
\hline Indonesia & & $x$ & & $x$ & & \\
\hline Japan & $x$ & & & & $\mathbf{x}$ & \\
\hline Korea, Rep. of & $x$ & & & $x$ & & \\
\hline Malaysia & $x$ & & & & $\mathbf{x}$ & \\
\hline Philippines & & $\mathbf{x}$ & & & $\mathbf{x}$ & \\
\hline Singapore & & $\mathbf{x}$ & & & $x$ & \\
\hline Thailand & $\mathbf{x}$ & & & & $\mathbf{x}$ & \\
\hline
\end{tabular}

Note: Hong Kong and Taiwan are not included in the survey.

Source: UN (various years). 
Table 13: Government Policy on the Level of Migration, ESEA: 1983 versus 1993

\begin{tabular}{|c|c|c|c|c|c|c|}
\hline \multirow[b]{3}{*}{ Country } & \multicolumn{6}{|c|}{ IMMIGRATION } \\
\hline & \multicolumn{3}{|c|}{ Policy in 1983} & \multicolumn{3}{|c|}{ Policy in 1993} \\
\hline & Raise & $\frac{\text { Maintain }}{x}$ & Lower & Raise & $\frac{\text { Maintain }}{x}$ & Lower \\
\hline Indonesia & & $x$ & & & & $x$ \\
\hline Japan & & $x$ & & & $x$ & \\
\hline Korea, Rep. of & & $x$ & & & $x$ & \\
\hline Malaysia & & $x$ & & & $x$ & \\
\hline Philippines & & $x$ & & & $x$ & \\
\hline Singapore & & $x$ & & & & $x$ \\
\hline Thailand & & $x$ & & & & $x$ \\
\hline
\end{tabular}

\begin{tabular}{|c|c|c|c|c|c|c|}
\hline \multirow[b]{3}{*}{ Country } & \multicolumn{6}{|c|}{ EMIGRATION } \\
\hline & \multicolumn{3}{|c|}{ Policy in 1983} & \multicolumn{3}{|c|}{ Policy in 1993} \\
\hline & Raise & Maintain & Lower & Raise & Maintain & Lower \\
\hline$\overline{\text { China }}$ & & $x$ & & & $x$ & \\
\hline Indonesia & & $x$ & & $x$ & & \\
\hline Japan & $x$ & & & & $x$ & \\
\hline Korea, Rep. of & $x$ & & & $x$ & & \\
\hline Malaysia & & $x$ & & & $x$ & \\
\hline Philippines & & $x$ & & & $x$ & \\
\hline Singapore & & $x$ & & & $\mathbf{x}$ & \\
\hline Thailand & $x$ & & & & $x$ & \\
\hline
\end{tabular}

Note: Hong Kong and Taiwan are not included in the survey.

The policy options indicate the following: "Raise" -- government intervention to raise rates; "Maintain" -- government intervention to maintain rates, or no direct intervention; "Lower" -- government intervention to lower rates.

Source: UN (various years). 
Table 14: Growth Rates of Trade for Australia, 1979-92

\begin{tabular}{lcc}
\hline Region & Exports to & Imports from \\
ESEA & 0.082 & 0.082 \\
Rest of world & 0.046 & 0.058 \\
Total & 0.064 & 0.066 \\
\hline
\end{tabular}

Note: The growth rates are slope coefficients from regression equations of the following form: $\log X_{t}=\alpha_{0}+\alpha_{1} t$, where $X_{t}$ is the nominal value of exports for the relevant regional grouping in year $t$.

Source: IMF (various years). 